Eurasscience Journals

Eurasian Journal of Forest Science (2016) 4(2): 18-29

\title{
IMPACT OF DRY SEASON FIRE ON TREE DIVERSITY OF A TROPICAL DRY FOREST IN BANDIPUR NATIONAL PARK, SOUTH INDIA
}

\author{
H. S. Suresh*, K. Sravan Kumar, and R. Sukumar \\ Center for Ecological Sciences Indian Institute of Science Bangalore 560012 Corresponding Author: H.S. \\ Suresh suresh@,ces.iisc.ernet.in Phone: 91-80-23600382 Fax: 91-80-23601429
}

\begin{abstract}
A study was conducted at the tropical dry forest of Bandipur, south India, to understand the impact of dry season fire on survival and mortality of different species. A total of 4235 trees belonging to 66 species were enumerated in both burnt and un-burnt areas of Bandipur National Park. Standard vegetation indices were calculated to characterize the natural vegetation of the park. Of the total 2679 trees were recorded from burnt area. Fire resulted in mortality of 679 trees belonging to 33 species. Tectona grandis (Teak) suffered maximum mortality because of fire followed by Anogeissus latifolia. Large proportion of Anogeissus latifolia and Terminalia crenulata trees survived the fire. Mortality of different species was significantly related to the population sizes of each species and also the survival of each species. There was a disproportionate mortality across different size classes.
\end{abstract}

Key words: Tropical dry forest, Bandipur, tree diversity, fire, mortality, survival

\section{Özet}

Bu çalışmada Hindistan'ın güneyinde bulunan Bandipur bölgesindeki kurak tropikal ormanlarda, kurak mevsim yangınlarının farklı türlerin hayatta kalma performansları üzerindeki etkileri araştırılmıştır. Bandipur millî parkında yangın geçirmiş ve yanmamış alanlarda bulunan 66 türe ait 4235 ağaç numaralandırılmıştır. Millî parktaki doğal bitki örtüsünü tanımlamak için standart indislere başvurularak hesaplamalar yapılmıştır. Yangın geçirmiş alanda 2679 adet ağaç tespit edilmiştir. Yang1n 33 türe ait 679 ağaç bireyini kurutmuştur. Anogeissus latifolia'dan sonra yanan Tectona grandis (Tik) türü yangından en fazla zarar gören tür olmuştur. Anogeissus latifolia ve Terminalia crenulate türlerine ait bireylerin çoğu yangından kurtulmuştur. Farklı türlere ait bireylerin hayatta kalma veya kalamamasının, her bir türe ait toplum büyüklüğü ve hayatta kalma gücüne anlamlı derecede bağlı olduğu tespit edilmiştir. Farklı büyüklüklerdeki bireyler arasında yaşamını yangın neticesinde yitirmeleri bakımından orantısızlık bulunduğu gözlemlenmiştir.

Anahtar kelimeler: Tropikal kurak orman, Bandipur, ağaç çeşitliliğii, yangın, ölüm, hayatta kalma.

\section{INTRODUCTION}

Ever since early hunter and gatherer groups learnt to use the fire about 50, 000 years ago, fire has been an integral part of the human life (Gadgil and Meher-Homji 1985; Saha, 2003).
Fires have been used extensively to clear forested landscapes for agriculture intentionally for example "Jhum" one of the slash and burn practice, is prevalent in northeast India, "podu" cultivation of ragi (Eleusine corocana) in south India to raise teak 
plantations after clearing forests. There could be accidental fires due to usage of forests. The incidences, intensity and scale of destruction by natural fires probably because of lightening are still largely unknown. However, in peninsular India the fires are attributed to humans. It is argued that fragmentation of landscapes and expansion of agriculture has made forested landscapes more prone to fire incidences (Gadgil \& Guha, 1993, Kodandapani et al 2004).

Fire as a natural disturbance factor in dry forests is a matter of debate; however, it is argued that dry forests did not evolve under selection pressure of fire (Saha \& Howe 2001; Saha 2002). Human induced fires are said to cause savannization of forested landscapes by hampering regeneration of species and altering the structure of forests (Saha 2001; Saha \& Howe 2006). Wild fires are characterized by intensity, residence time and return interval. Each of these factors has significant influence on the vegetation. Nature and characteristics of the fire depends on the local weather conditions.

Fires in Indian context have been used in the past as a management regime to stimulate germination of important timber species such as teak (Tectona grandis) and sal (Shorea robusta). However, our understanding on the impacts of dry season fire is limited. Studies on wildfire have focused on extent and damage in an area (Somashekar et al 2009), fire regimes (Saha 2002), impact on diversity by causing seedling mortality and enhancing clonal propagation (Saha \& Howe 2003), increasing fire frequencies across peninsular India (Kodanpani et al 2004) and ecological characteristics of dry season fires (Kodandapani et al 2008). The impact of dry season fire on forest dynamics is being carried out in dry forests of Mudumalai by research team from Indian Institute of Science (Sukumar et al 1998, 2005)

The objective of this current study is to understand the impact of canopy fire that swept through some parts of Bandipur National Park. Specifically we ask following questions 1.What is the observed mortality pattern? 2. How many species survived the fire? 3. Is there a size class specific mortality because of fire?

\section{MATERIALS AND METHODS Site description}

Present study was carried out in Bandipur National Park (BNP) $\left(11^{\circ} 35^{\prime} \mathrm{N}-11^{\circ} 58 \mathrm{~N}\right.$ latitude, $76^{\circ} 12^{\prime} \mathrm{E}-76^{\circ} 53^{\prime} \mathrm{E}$ longitude). BNP was declared tiger reserve in 1972 and it is a national park. BNP was included in Nilgiri Biosphere Reserve (NBR), the country's first biosphere reserve in 1986. BNP has to the north the dry Deccan plateau, to the west it has Nagerhole National Park, to the east is a conglomeration of settlements and forest while to the south it has Mudumalai Tiger Reserve (Tamilnadu). Topography is generally undulating with elevations ranging from 700 meters ASl to 1450 meters ASL (Gopalaswamy betta) with a deep gorge towards south-east of the park that is a political boundary between Karnataka and Tamilnadu. Perennial rivers that drain the park are the Moyar and the Kabini. Geologically BNP is classified under granitegneiss complex of the Archean group with chief rocks being gneiss, granites and charnockites Climate is tropical savanna, hot and seasonally dry tropical in nature with distinct wet and dry seasons (IMD, 1984). . It has temperature ranging from $10^{\circ} \mathrm{C}$ during the cold season to $35^{\circ} \mathrm{C}$ during the hot season. Rainfall is mostly from southwest monsoon during the months of JuneSeptember. Retreating monsoon is active during October-November that brings rain to the eastern part. Rainfall in the park varies from 800 to $1600 \mathrm{~mm}$ per annum. Because of topography there is a distinct rainfall gradient along east (dry) and west (wet) direction. Hence the vegetation also varies along this direction with tropical moist deciduous forests (west) to tropical dry thorn forests (east) through tropical dry deciduous forests largely in the central part of the park. Largely vegetation of $\mathrm{BNP}$ has been classified as woodland - savanna type under broad category of tropical dry deciduous forest (teak dominated). Vegetation is characterized by Anogeissus-Tectona-Terminalia association (Pascal 1982). Floristics of the park is dominated by species such as Anogeissus latifolia, Terminalia crenulata, Tectona grandis. Other important canopy trees include Pterocarpus marsupium, Dalbergia latifolia, Shorea roxburghii (only 
dipterocarp in dry forest), Stereospermum personatum and Adina cordifolia. The understorey include species such as Cassia fistula, Phyllanthus emblica, and Kydia calycina. Ground flora is dominated by tall perennial grass species such as Themeda cymbaria, Themeda triandra, Cymbopogon flexosus and Imperata cylindrica. Herbaceous species include several species belonging to families such as Fabaceae, Lamiaceae and Apiaceae. (Prasad \& Sharatchandra, 1994; Prasad 2009). Quantitative description of the vegetation is given in (Mehta et al. 2008a). Detailed description of the study area is given in (Somashekar et al. 2009; Mehta et al. 2008 b; Puyravaud et al. 1992; Prasad \& Hedge 1986; Sharatchandra \& Gadgil 1977).

We followed plot less method for enumeration. We enumerated trees $>1 \mathrm{~cm}$ dbh (diameter at breast height) in both burnt and un-burnt areas. We decided the perimeter of the burnt area with help of trees having distinct signs of burning and also with local knowledge of forest guards and watchers. We enumerated trees for the species, measured their sizes and estimated their heights qualitatively. Cause of the death was ascertained after inspection of trees for fire marks, elephant debarking or other symptoms. The causes were classified as fire related mortality; elephant related mortality

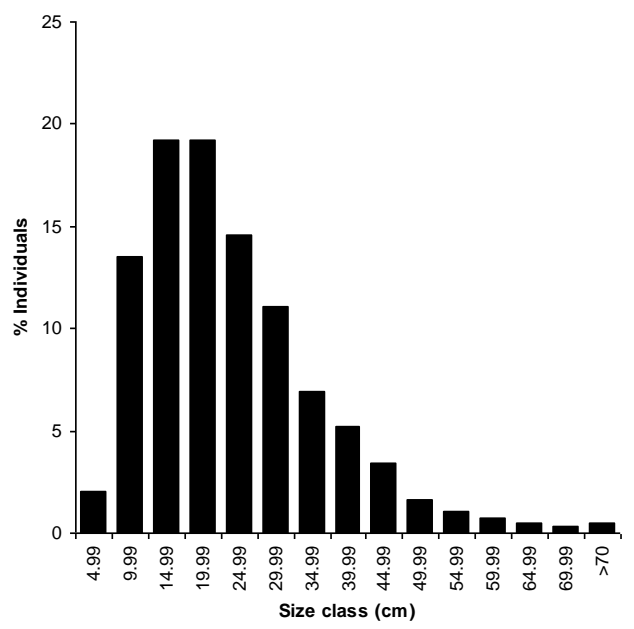

and all others were put in other causes. Data was also kept on trees that survived the fire.

\section{RESULTS}

A total of 4235 trees belonging to 66 species were enumerated from both burnt and unburnt areas in the national park. Community wide measure of heterogeneity (ShannonWeiner's ( $H^{\prime}$ ) index) was 2.46 and probability of picking two species (Simpson's index) was 0.81 . Fisher's alpha was 11.1. Evenness and dominance of a particular species were low indicating multi-species dominance in the forest. Most abundant species was Anogeissus latifolia $(37.45 \%)$, followed by Tectona grandis $(13.93 \%)$ and Terminalia crenulata (11.33\%). These three species accounted for a total of $62.7 \%$ of total abundance. Top ten species accounted for $83 \%$ of the total abundance (Table 1). There were twelve species with one individual each. Overall size class distribution of individuals showed a typical inverted "J" distribution (Fig. 1). There $80 \%$ of individuals below $30 \mathrm{~cm} \mathrm{DBH}$ and there was large concentration of individuals between $5-25 \mathrm{~cm}$ dbh $(67 \%)$ suggesting that BNP is relatively a young or recovering(secondary) forest. There was only $1.2 \%$ of individuals which were above $>60 \mathrm{~cm} \mathrm{dbh}$. There were large numbers of individuals in 6-8 meter height class (21\%).

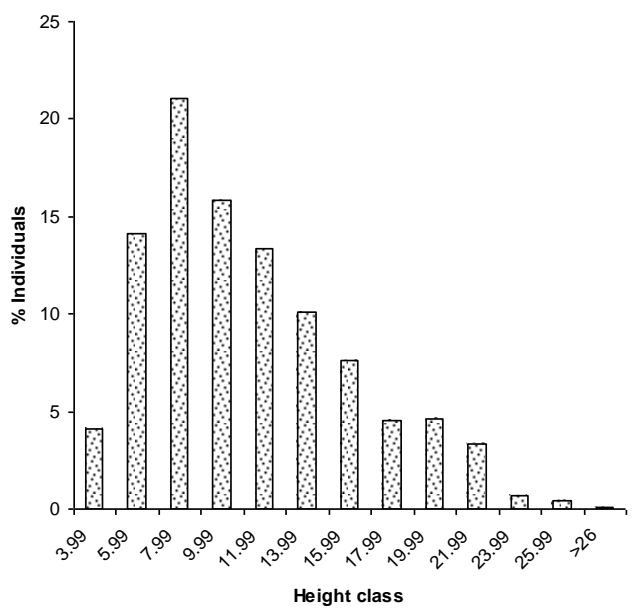

Figure 1. Community wide distribution of individuals in various size classes at Bandipur National Park. 
Figure 2. Height class distribution of Individuals in BNP

Table 1. Abundabces of top ten species in BNP

\begin{tabular}{|l|l|l|l|l|}
\hline Sl. No & Species (Family) & $\begin{array}{l}\text { Number of } \\
\text { Individuals }\end{array}$ & $\begin{array}{l}\text { Relative } \\
\text { abundance }(\%)\end{array}$ & $\begin{array}{l}\text { Cumulative } \\
\text { Abundance } \\
(\%)\end{array}$ \\
\hline 1 & Anogeissus latifolia (Combretaceae) & 1586 & 37.44 & 37.44 \\
\hline 2 & Tectona grandis (Verbenaceae) & 590 & 13.93 & 51.38 \\
\hline 3 & Terminalia crenulata (Combretaceae) & 480 & 11.33 & 62.71 \\
\hline 4 & Phyllanthus emblica (Euphorbiaceae) & 314 & 7.41 & 70.12 \\
\hline 5 & Shorea robusta (Dipterocarpaceae) & 133 & 3.14 & 73.27 \\
\hline 6 & Shrebera switenioides (Oleaceae) & 103 & 2.43 & 75.70 \\
\hline 7 & Terminalia chebula (Combretaceae) & 103 & 2.43 & 78.13 \\
\hline 8 & $\begin{array}{l}\text { Grewia tiliifolia } \\
\text { (Tiliaceae) }\end{array}$ & 85 & 2.00 & 80.14 \\
\hline 9 & Lagerstroemia parvifolia (Lythraceae) & 68 & 1.60 & 81.74 \\
\hline 10 & Dalbergia lanceolaria (Fabaceae) & 55 & 1.28 & 83.04 \\
\hline
\end{tabular}

About $75 \%$ of the stand was between 4 and 14 meter height. There were about $4 \%$ of trees above 20 meters in height (Fig. 2). As the enumeration did not assume any dimension; we are expressing the basal area as per tree basis. The total basal area was $213.2 \mathrm{~m}^{2}$ from 4406 individuals that were enumerated resulting in $0.048 \mathrm{~m}^{2}$ per tree. But this number

A total of 2679 trees belonging to 65 species were enumerated in the burnt area. A total of $679(25.3 \%)$ trees belonging to 33 species found dead because of fire. Anogeissus latifolia $(26.7 \%)$ and Tectona grandis $(55.5 \%)$ suffered maximum mortality (Table 2). There were 68 $(2.53 \%)$ trees dead because of "other causes" and elephants. There were 841 (31.3\%) trees survived after they were impacted by fire. None of the species recorded $100 \%$ mortality. The survival rates varied across species for example species such as Cordia obliqua, Hyminodictyon orixense, Schleichera oleosa, varies between size classes. For example trees in $25-30 \mathrm{~cm}$ dbh class which accounts for $11.09 \%$ of total stand accounts for $13.5 \%$ of total basal area resulting in $0.0589 \mathrm{~m}^{2}$ per tree. But trees above $70 \mathrm{~cm}$ dbh which accounts for $0.4 \%$ of total stand had $5.4 \%$ of the total basal area resulting in $0.52 \mathrm{~m}^{2}$ per tree.

Scherebera switeniodes, Stereospermum personatum and Radermachera xylocarpa had more than $50 \%$ survival rate while species such as Anogeissus latifolia had $29.6 \%$ and Tectona grandis $33.5 \%$ as the survival rate (Table 2). A total of $40.7 \%$ (1091 trees) trees were not affected by fire. Species such as Boswelia serrata, Fluggea leucopyros and Phyllanthus indofischeri were not impacted by fire at all (Table 2). Among the dominant species such as Anogeissus latifolia, Tectona grandis and Terminalia crenulata 41.1\%, $7.6 \%$ and $48.2 \%$ of the population was not impacted by fire. 
Table 2. Survival and mortality of species impacted by dry season fire in BNP.

\begin{tabular}{|c|c|c|c|c|}
\hline Sl. No & Species (Family) & $\begin{array}{l}\text { Number of } \\
\text { Individuals }\end{array}$ & Mortality $(\%)$ & $\begin{array}{l}\text { Survival after } \\
\text { fire }(\%)\end{array}$ \\
\hline 1 & $\begin{array}{l}\text { Anogeissus latifolia } \\
\text { (Combretaceae) }\end{array}$ & 991 & 26.74 & 29.96 \\
\hline 2 & Tectona grandis (Verbenaceae) & 394 & 55.58 & 33.5 \\
\hline 3 & $\begin{array}{l}\text { Terminalia crenulata } \\
\text { (Combretaceae) }\end{array}$ & 255 & 20.78 & 29.80 \\
\hline 4 & $\begin{array}{l}\text { Phyllanthus emblica } \\
\text { (Euphorbiaceae) }\end{array}$ & 174 & 18.96 & 16.66 \\
\hline 5 & $\begin{array}{l}\text { Shorea roxburghii } \\
\text { (Dipterocarpaceae) }\end{array}$ & 1 & 100 & 0 \\
\hline 6 & Shrebera switenioides (Oleaceae) & 9 & 11.11 & 88.88 \\
\hline 7 & Terminalia chebula (Combretaceae) & 52 & 7.96 & 23.07 \\
\hline 8 & Grewia tiliifolia (Tiliaceae) & 59 & 3.38 & 11.86 \\
\hline 9 & $\begin{array}{l}\text { Lagerstroemia parvifolia } \\
\text { (Lythraceae) }\end{array}$ & 73 & 24.6 & 26.02 \\
\hline 10 & Dalbergia lanceolaria (Fabaceae) & 55 & 0 & 4.54 \\
\hline 11 & Randia dumetorum (Rubiaceae) & 50 & 22.0 & 24.0 \\
\hline 12 & Cassia fistula (Fabcaeae) & 36 & 16.6 & 44.4 \\
\hline 13 & Pterocarpus marsupium (Fabcaeae) & 35 & 20.0 & 20.0 \\
\hline 14 & Ziziphus xylopyrus (Rhmnaceae) & 28 & 10.71 & 25.0 \\
\hline 15 & Bridelia retusa (Euphorbiaceae) & 35 & 20.0 & 20.0 \\
\hline 16 & $\begin{array}{l}\text { Stereospermum personatum } \\
\text { (Bignoniaceae) }\end{array}$ & 38 & 15.78 & 71.05 \\
\hline 17 & Premna tomentosa (Verbenaceae) & 37 & 0.0 & 45.94 \\
\hline 18 & $\begin{array}{l}\text { Terminalia paniculata } \\
\text { (Combretaceae) }\end{array}$ & 11 & 9.09 & 18.18 \\
\hline 19 & $\begin{array}{l}\text { Hyminodiction orixense } \\
\text { (Rubiaceae) }\end{array}$ & 30 & 23.33 & 73.33 \\
\hline 20 & Schleichera oleosa (Sapindaceae) & 27 & 7.40 & 92.59 \\
\hline 21 & Bauhinia racemosa (Fabaceae) & 25 & 0 & 36.0 \\
\hline 22 & Cassine glauca (celastraceae) & 26 & 15.38 & 23.07 \\
\hline 23 & Cordia obliqua (Boraginaceae) & 26 & 19.23 & 11.53 \\
\hline 24 & Cordia wallichii (Boraginaceae) & 12 & 16.66 & 83.33 \\
\hline 25 & Grewia sp. (Tiliaceae) & 20 & 0 & 10.0 \\
\hline 26 & Careya arborea (Lecythidaceae) & 12 & 16.66 & 25.0 \\
\hline 27 & Diospyros montana (Ebenaceae) & 18 & 22.22 & 33.33 \\
\hline 28 & Randia tamilnadensis (Rubiaceae) & 1 & 0 & 0 \\
\hline 29 & Vitex altissima (Verbenaceae) & 15 & 20.0 & 13.33 \\
\hline 30 & Dalbergia latifolia (Fabcaeae) & 10 & 30.0 & 40.0 \\
\hline 31 & $\begin{array}{l}\text { Radermachera xylocarpa } \\
\text { (Bignoniaceae) }\end{array}$ & 12 & 8.33 & 66.66 \\
\hline 32 & $\begin{array}{l}\text { Erythroxylon monogynum } \\
\text { (Linaceae) }\end{array}$ & 12 & 0 & 0 \\
\hline 33 & Butea monosperma (Fabaceae) & 8 & 0 & 0 \\
\hline 34 & Cassia spectabilis (Fabaceae) & 8 & 12.5 & 87.5 \\
\hline
\end{tabular}




\begin{tabular}{|c|c|c|c|c|}
\hline 35 & Acacia chundra (Fabaceae) & 7 & 14.28 & 0 \\
\hline 36 & $\begin{array}{l}\text { Semecarpus anacardium } \\
\text { (Anacardiaceae) }\end{array}$ & 3 & 0 & 33.33 \\
\hline 37 & Bombax cieba (Bombacaceae) & 6 & 0 & 83.33 \\
\hline 38 & Mitragyna parviflora (Rubiaceae) & 6 & 0 & 100 \\
\hline 39 & $\begin{array}{l}\text { Stereospermum atrovirens } \\
\text { (Bignoniaceae) }\end{array}$ & 6 & 16.66 & 0 \\
\hline 40 & Cordia obliqua (Boraginaceae) & 26 & 19.23 & 11.53 \\
\hline 41 & Ficus benghalensis (Moraceae) & 4 & 0 & 50 \\
\hline 42 & Plurostylis (Celastraceae) & 1 & 100 & 0 \\
\hline 43 & Cipadessa baccifera (Meliaceae) & 4 & 75.0 & 25.0 \\
\hline 44 & $\begin{array}{l}\text { Erioleana quinquilocularis } \\
\text { (Sterculiaceae) }\end{array}$ & 4 & 50.0 & 50.0 \\
\hline 45 & Casearia esculenta (Flacourtiaceae) & 2 & 0 & 100 \\
\hline 46 & $\begin{array}{l}\text { Givotia rottleriformis } \\
\text { (Euphorbiaceae) }\end{array}$ & 3 & 0 & 33.33 \\
\hline 47 & $\begin{array}{l}\text { Maytenus emarginata } \\
\text { (Celastraceae) }\end{array}$ & 3 & 0 & 0 \\
\hline 48 & Acacia leucophloea (Fabaceae) & 2 & 0 & 50 \\
\hline 49 & Boswelia serrata (Burseraceae) & 2 & 0 & 0 \\
\hline 50 & Garuga pinnata (Burseraceae) & 2 & 0 & 100 \\
\hline 51 & Gmelina arborea (Verbenaceae) & 1 & 0 & 0 \\
\hline 52 & Madhuca neeriifolia (Sapotaceae) & 2 & 0 & 50 \\
\hline 53 & Moringa (Moringaceae) & 2 & 0 & 0 \\
\hline 54 & $\begin{array}{l}\text { Phyllanthus indofischeri } \\
\text { (Euphorbiaceae) }\end{array}$ & 2 & 0 & 0 \\
\hline 55 & Albizia odoratissima (Fabaceae) & 2 & 0 & 100 \\
\hline 56 & $\begin{array}{l}\text { Antidesma menasu } \\
\text { (Euphorbiaceae) }\end{array}$ & - & - & - \\
\hline 57 & Bauhinia malabarica (Fabaceae) & 2 & 0 & 50 \\
\hline 58 & Buchanannia lanzan (Ancardiaceae) & 1 & 0 & 100 \\
\hline 59 & $\begin{array}{l}\text { Flacourtiaceae indica } \\
\text { (Flacourtiaceae) }\end{array}$ & 1 & 0 & 100 \\
\hline 60 & $\begin{array}{l}\text { Fluggea leucopyros } \\
\text { (Euphorbiaceae) }\end{array}$ & 1 & 0 & 0 \\
\hline 61 & $\begin{array}{l}\text { Gyrocarpus jacqinus } \\
\text { (Hernandiaceae) }\end{array}$ & 1 & 0 & 0 \\
\hline 62 & $\begin{array}{l}\text { Lannea coromandelica } \\
\text { (Anacardiaceae) }\end{array}$ & 1 & 2 & 100 \\
\hline 63 & Morinda tinctoria (Apocyanaceae) & 2 & 0 & 0 \\
\hline 64 & Syzygium cumini (Myrtaceae) & - & - & - \\
\hline 65 & $\begin{array}{l}\text { Terminalia bellerica } \\
\text { (Combretaceae) }\end{array}$ & 1 & 0 & 100 \\
\hline
\end{tabular}

Mortality of trees because of fire across various species was significantly related to population sizes of species in the stand $(\mathrm{r}=$ $0.94, p>0.0001)$ also the survival of trees after fire $(\mathrm{r}=0.99, \mathrm{p}>0.0001)$ and trees not affected by fire $(\mathrm{r}=0.94, \mathrm{p}>0.0001)$ was significantly related to population sizes of various species. Percent mortality of species because of fire and their survival percent were not related $(\mathrm{r}=-0.21, \mathrm{p}>0.08)$, however, there was a negative trend. Trees between 10 and 25 $\mathrm{cm}$ dbh class suffered high mortality which 
accounted for $46 \%$ of the total mortality (Fig. 3). The mortality across size classes was significantly different from stand. There is a disproportionate mortality across size classes (KS test, $\mathrm{D}=0.7272, \mathrm{p}<0.01)$. Survival of trees across various size classes was also

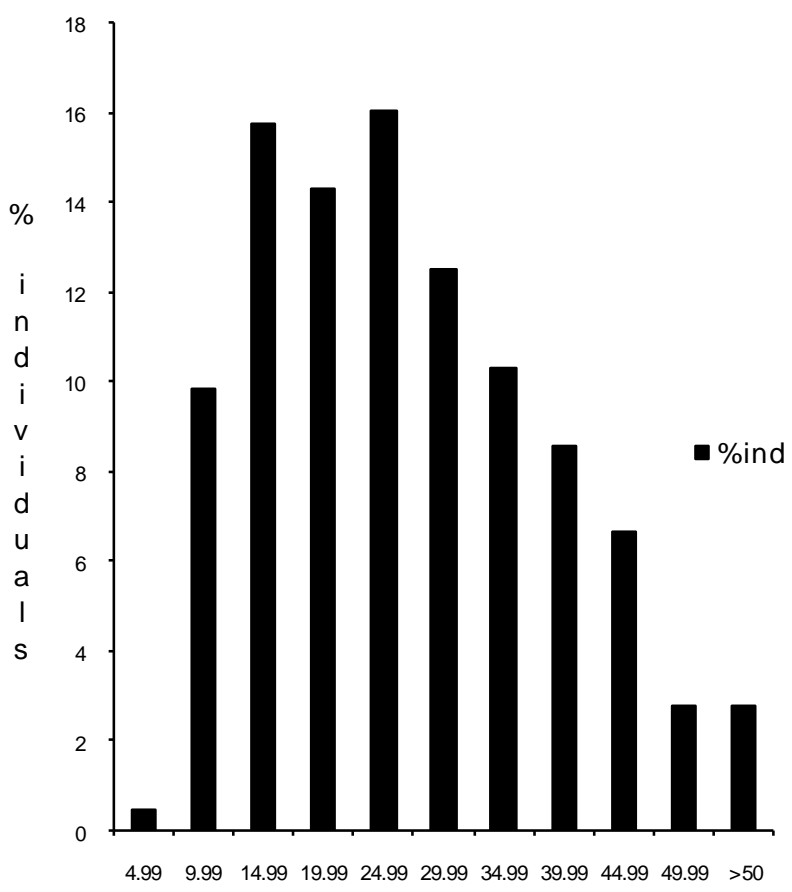

Size class significantly different from the stand (KS test, $\mathrm{D}=0.6363, \mathrm{p}<0.02)$. Large proportions of trees were not affected by fire in less than 5 $\mathrm{cm}$ dbh class. But among trees in $20-50 \mathrm{~cm}$ size class there was high mortality between $30 \%$ and $40 \%$ observed.

Figure 3. Mortality of individuals in different size classes

Among trees over $50 \mathrm{~cm}$ dbh class, though many of them were impacted by fire and large number of them $(>70 \%)$ survived after a mega fire. Large numbers of trees were not affected by fire in the 5 to $25 \mathrm{~cm}$ dbh class.

\section{DISCUSSION}

Anthropogenic fires in dry forests of India are a regular event. These forests have experienced the fire for thousands of years (Gadgil \& Chandran 1988). These fires are set for different reasons including facilitation of NTFP collection. The ecology of dry season ground fires in dry forests of India are yet to be studied in depth, However, there are studies in central and south India in this direction. Saha (2002) has characterized the intensity of fire in dry forests of central India through temperature as a proxy. She found that the temperature of dry season fire ranged from $316^{\circ} \mathrm{C}$ to $510^{\circ} \mathrm{C}$ during April and $<45^{\circ} \mathrm{C}$ to $510{ }^{\circ} \mathrm{C}$ in March fires. Temperatures of fire varied from $79^{\circ} \mathrm{C}$ to $760^{\circ} \mathrm{C}$ in dry forests of south India but, mostly around $500^{\circ} \mathrm{C}$ in many cases (Mondal pers.comm). Intensity of fires depends on the spatial variation in fuel load and local weather conditions of that day. Saha (2002), has characterized the fire return interval of one year for central Indian dry forests. Kodandapani et al. (2004), has estimated fire return interval for dry forests in south India to be 3.3 years and has found that this interval is increasing over the last century. These factors that characterize the dry season fires, ultimately suggested to affect the diversity and 
structure of forests (Saha \& Howe 2001; 2009)

Forest fires in BNP have not been characterized except for the spatial extent of spread and identification of fire prone areas with satellite images (Somashekar et al. 2009). Puyravaud et al. (1995), did report that less fire prone area had high tree density and high fire prone area had low tree density. Low tree density plots also suffered high sapling mortality though the regeneration was high. Our study however focused on impacts of canopy fire that spread through after a long years of protection from fire.

An overall mortality of $25 \%$ of standing stems from the past three fires is on the higher side compared to mortality figures reported from dry forests of Mudumalai (Sukumar et al. 1998; 2005). Mortality figures for dry forests of Mudumalai for stems $>1 \mathrm{~cm}$ dbh is $7.62 \pm 4.84(4.04-16.27, \mathrm{~N}=6)$ during the fire years. (Sukumar et al. unpublished results from 50 ha plot (1988-2008), fire years were 1989, $91,92,95,96,2002)$ while for the stems between $10 \mathrm{~cm}$ to $30 \mathrm{~cm}$ dbh it was $0.59 \pm 0.41(0.197-1.397)$ and for stems $>30 \mathrm{~cm}$ it was $0.16 \pm 0.137(0.00-0.356)$. Species such as Anogeissus latifolia and Tectona grandis suffered high mortality. Mortality was also proportional to density of each species.

It is suggested that dry season fires reduces the diversity of forests by killing saplings and additionally suppresses the growth of saplings so as to alter the structure of the forest(Saha \& Howe 2003; 2009). This prompts us to ask the question whether there is a change in the diversity of BNP landscape after the fire and is there a compositional shift in terms of abundance pattern of at least dominant species? There was a small change in absolute number of species after the fire. Species number reduced from 65 to 63 species by loosing Shorea roxburghii (Dipterocarpaceae) and Pleurostylis wightii (Ceastraceae). There is a slight increase in the heterogeneity of the system from 2.54 to 2.67 which may not be significant. There was no compositional change and minor change in the abundance pattern of species. In both cases Anogeissus latifolia, dominated the floristics. However there is shuffle in the ranks of some species. For example, Tectona grandis which ranked second before fire with a loss of $58.8 \%$ of its population, was the third abundant species after fire. Terminalia crenulata with a loss of $21.9 \%$ of the population became the second abundant species after fire (Table 3). Most species have shown declining trend in the population. Among the abundant species large change was seen in Tectona grandis (-58.8\%), followed by Anogeissus latifolia (-28\%), Lagerstroemia parviflora (-26\%). The species that have shown either low or no changes were Premna tomentosa (0\%), Grewia tiliifolia (3\%) and Dalbergia lanceolaria $(1.18 \%)$. At this stage it is not possible to speculate the reasons for their decline. There could be plethora of explanations including both biological and environmental factors. The speculated compositional and diversity changes may require long-term observations and even with 24 years of study on dynamics of dry forests, there was no shift observed in the floristic composition of dry forests in Mudumalai (Sukumar et al. unpublished results).

Table 3: Changes in the abundance and ranks in several species impacted by dry season fire in BNP.

\begin{tabular}{|l|l|l|l|l|l|}
\hline Species & $\begin{array}{l}\text { Abundance } \\
\text { prior to fire }\end{array}$ & $\begin{array}{l}\text { Abundance } \\
\text { after fire }\end{array}$ & $\begin{array}{l}\% \\
\text { Change }\end{array}$ & $\begin{array}{l}\text { Rank } \\
\text { before } \\
\text { fire }\end{array}$ & $\begin{array}{l}\text { Rank after } \\
\text { fire }\end{array}$ \\
\hline $\begin{array}{l}\text { Anogeissus latifolia } \\
\text { (Combretaceae) }\end{array}$ & 991 & 705 & -28.85 & 1 & 1 \\
\hline $\begin{array}{l}\text { Terminalia crenulata } \\
\text { (Combretaceae) }\end{array}$ & 255 & 199 & -21.96 & 3 & 2 \\
\hline $\begin{array}{l}\text { Tectona grandis } \\
\text { (Verbenaceae) }\end{array}$ & 394 & 162 & -58.88 & 2 & 3 \\
\hline $\begin{array}{l}\text { Phyllanthus emblica } \\
\text { (Euphorbiaceae) }\end{array}$ & 174 & 136 & -21.83 & 4 & 4 \\
\hline
\end{tabular}




\begin{tabular}{|c|c|c|c|c|c|}
\hline Grewia tiliifolia (Tiliaceae) & 59 & 57 & -3.38 & 6 & 5 \\
\hline $\begin{array}{l}\text { Lagerstroemia parvifolia } \\
\text { (Lythraceae) }\end{array}$ & 73 & 54 & -26.02 & 5 & 6 \\
\hline $\begin{array}{l}\text { Dalbergia lanceolaria } \\
\text { (Fabaceae) }\end{array}$ & 55 & 54 & -1.81 & 7 & 7 \\
\hline $\begin{array}{l}\text { Terminalia chebula } \\
\text { (Combretaceae) }\end{array}$ & 52 & 48 & -7.69 & 8 & 8 \\
\hline $\begin{array}{l}\text { Premna tomentosa } \\
\text { (Verbenaceae) }\end{array}$ & 37 & 37 & 0 & 11 & 9 \\
\hline $\begin{array}{l}\text { Randia dumetorum } \\
\text { (Rubiaceae) }\end{array}$ & 50 & 33 & -34.0 & 9 & 10 \\
\hline $\begin{array}{l}\text { Stereospermum personatum } \\
\text { (Bignoniaceae) }\end{array}$ & 38 & 31 & -18.4 & 10 & 11 \\
\hline Cassia fistula (Fabcaeae) & 36 & 29 & -19.44 & 12 & 12 \\
\hline $\begin{array}{l}\text { Bridelia retusa } \\
\text { (Euphorbiaceae) }\end{array}$ & 35 & 29 & -17.14 & 13 & 13 \\
\hline $\begin{array}{l}\text { Schleichera oleosa } \\
\text { (Sapindaceae) }\end{array}$ & 27 & 25 & -7.40 & 17 & 14 \\
\hline $\begin{array}{l}\text { Ziziphus xylopyrus } \\
\text { (Rhmnaceae) }\end{array}$ & 28 & 24 & -14.28 & 16 & 15 \\
\hline $\begin{array}{l}\text { Pterocarpus marsupium } \\
\text { (Fabcaeae) }\end{array}$ & 35 & 23 & -34.28 & 14 & 16 \\
\hline $\begin{array}{l}\text { Hyminodiction orixense } \\
\text { (Rubiaceae) }\end{array}$ & 30 & 23 & -23.33 & 15 & 17 \\
\hline $\begin{array}{l}\text { Bauhinia racemosa } \\
\text { (Fabaceae) }\end{array}$ & 25 & 23 & -8.0 & 20 & 18 \\
\hline Cassine glauca (celastraceae) & 26 & 22 & -15.38 & 19 & 19 \\
\hline Grewia sp. (Tiliaceae) & 20 & 20 & 0.0 & 21 & 20 \\
\hline $\begin{array}{l}\text { Cordia obliqua } \\
\text { (Boraginaceae) }\end{array}$ & 26 & 17 & -34.61 & 18 & 21 \\
\hline $\begin{array}{l}\text { Diospyros montana } \\
\text { (Ebenaceae) }\end{array}$ & 18 & 13 & -27.77 & 22 & 22 \\
\hline Vitex altissima (Verbenaceae) & 15 & 12 & -20.0 & 23 & 23 \\
\hline $\begin{array}{l}\text { Erythroxylon monogynum } \\
\text { (Linaceae) }\end{array}$ & 12 & 12 & 0.0 & 26 & 24 \\
\hline $\begin{array}{l}\text { Radermachera xylocarpa } \\
\text { (Bignoniaceae) }\end{array}$ & 12 & 11 & -8.33 & 27 & 25 \\
\hline $\begin{array}{l}\text { Careya arborea } \\
\text { (Lecythidaceae) }\end{array}$ & 12 & 10 & -16.66 & 24 & 26 \\
\hline $\begin{array}{l}\text { Cordia wallichii } \\
\text { (Boraginaceae) }\end{array}$ & 12 & 10 & -16.66 & 25 & 27 \\
\hline $\begin{array}{l}\text { Terminalia paniculata } \\
\text { (Combretaceae) }\end{array}$ & 11 & 10 & -9.09 & 28 & 28 \\
\hline $\begin{array}{l}\text { Shrebera switenioides } \\
\text { (Oleaceae) }\end{array}$ & 9 & 8 & -11.11 & 30 & 29 \\
\hline $\begin{array}{l}\text { Butea monosperma } \\
\text { (Fabaceae) }\end{array}$ & 8 & 8 & 0.0 & 31 & 30 \\
\hline Cassia spectabilis (Fabaceae) & 8 & 7 & -12.5 & 32 & 31 \\
\hline Dalbergia latifolia (Fabcaeae) & 10 & 6 & -40.0 & 29 & 32 \\
\hline Acacia chundra (Fabaceae) & 7 & 6 & -14.28 & 33 & 33 \\
\hline Bombax cieba & 6 & 6 & 0 & 34 & 34 \\
\hline
\end{tabular}




\begin{tabular}{|c|c|c|c|c|c|}
\hline (Bombacaceae) & & & & & \\
\hline $\begin{array}{l}\text { Mitragyna parviflora } \\
\text { (Rubiaceae) }\end{array}$ & 6 & 6 & 0 & 35 & 35 \\
\hline $\begin{array}{l}\text { Stereospermum atrovirens } \\
\text { (Bignoniaceae) }\end{array}$ & 6 & 5 & -16.66 & 36 & 36 \\
\hline $\begin{array}{l}\text { Ficus benghalensis } \\
\text { (Moraceae) }\end{array}$ & 4 & 4 & 0 & 40 & 38 \\
\hline $\begin{array}{l}\text { Givotia rottleriformis } \\
\text { (Euphorbiaceae) }\end{array}$ & 3 & 3 & 0 & 42 & 39 \\
\hline $\begin{array}{l}\text { Maytenus emarginata } \\
\text { (Celastraceae) }\end{array}$ & 3 & 3 & 0 & 43 & 40 \\
\hline $\begin{array}{l}\text { Semecarpus anacardium } \\
\text { (Anacardiaceae) }\end{array}$ & 3 & 3 & 0 & 44 & 41 \\
\hline $\begin{array}{l}\text { Erioleana quinquilocularis } \\
\text { (Sterculiaceae) }\end{array}$ & 4 & 2 & -50.0 & 39 & 42 \\
\hline Plurostylis (Celastraceae) & 4 & 2 & -50.0 & 41 & 43 \\
\hline $\begin{array}{l}\text { Acacia leucophloea } \\
\text { (Fabaceae) }\end{array}$ & 2 & 2 & 0.0 & 45 & 44 \\
\hline $\begin{array}{l}\text { Albizia odoratissima } \\
\text { (Fabaceae) }\end{array}$ & 2 & 2 & 0.0 & 46 & 45 \\
\hline $\begin{array}{l}\text { Bauhinia malabarica } \\
\text { (Fabaceae) }\end{array}$ & 2 & 2 & 0.0 & 47 & 46 \\
\hline $\begin{array}{l}\text { Boswelia serrata } \\
\text { (Burseraceae) }\end{array}$ & 2 & 2 & 0.0 & 48 & 47 \\
\hline $\begin{array}{l}\text { Casearia esculenta } \\
\text { (Flacourtiaceae) }\end{array}$ & 2 & 2 & 0.0 & 49 & 48 \\
\hline Garuga pinnata (Burseraceae) & 2 & 2 & 0.0 & 50 & 49 \\
\hline Moringa (Moringaceae) & 2 & 2 & 0.0 & 53 & 51 \\
\hline $\begin{array}{l}\text { Phyllanthus indofischeri } \\
\text { (Euphorbiaceae) }\end{array}$ & 2 & 2 & 0.0 & 54 & 52 \\
\hline $\begin{array}{l}\text { Cipadessa baccifera } \\
\text { (Meliaceae) }\end{array}$ & 4 & 1 & -75.0 & 38 & 53 \\
\hline $\begin{array}{l}\text { Madhuca neeriifolia } \\
\text { (Sapotaceae) }\end{array}$ & 2 & 1 & -50.0 & 52 & 54 \\
\hline $\begin{array}{l}\text { Buchanannia lanzan } \\
\text { (Ancardiaceae) }\end{array}$ & 1 & 1 & 0 & 55 & 55 \\
\hline $\begin{array}{l}\text { Flacourtiaceae indica } \\
\text { (Flacourtiaceae) }\end{array}$ & 1 & 1 & 0 & 56 & 56 \\
\hline $\begin{array}{l}\text { Fluggea leucopyros } \\
\text { (Euphorbiaceae) }\end{array}$ & 1 & 1 & 0 & 57 & 57 \\
\hline $\begin{array}{l}\text { Gyrocarpus jacqinus } \\
\text { (Hernandiaceae) }\end{array}$ & 1 & 1 & 0.0 & 58 & 58 \\
\hline $\begin{array}{l}\text { Lannea coromandelica } \\
\text { (Anacardiaceae) }\end{array}$ & 1 & 1 & 0.0 & 59 & 59 \\
\hline $\begin{array}{l}\text { Gmelina arborea } \\
\text { (Verbenaceae) }\end{array}$ & 1 & 1 & 0.0 & 60 & 60 \\
\hline $\begin{array}{l}\text { Randia tamilnadensis } \\
\text { (Rubiaceae) }\end{array}$ & 1 & 1 & 0.0 & 63 & 62 \\
\hline $\begin{array}{l}\text { Terminalia bellerica } \\
\text { (Combretaceae) }\end{array}$ & 1 & 1 & 0.0 & 65 & 63 \\
\hline Shorea roxburghii & 1 & 0 & -100 & 64 & 64 \\
\hline
\end{tabular}


(Dipterocarpaceae)

The compositional changes may be brought out by repeated top killing of seedlings (Saha \& Howe 2006; Geeta Ramaswami pers. comm.). Repeated fires could also result in structural modification by stunting the trees.

Canopy fires in BNP though resulted in large scale population change, there was no drastic change in either diversity or composition was observed. Large number of individuals survived after a major fire indicating the resilience of the dry forests. We need longterm studies on fire-forest interaction to understand the long-term impacts of repeated burning on the diversity and compositional changes in dry forests. There should be pragmatic and area specific policy on dry season fires in the country.

But we can expect structural changes in the forests of BNP. The conspicuous absence of individuals in the lower size classes may possibly be attributed to frequent ground fires and occasional canopy fires that sweeps through the forests. These speculations could be strengthened by long-term observations on incidences of fire and response of the vegetation.

\section{CONCLUSIONS}

The central zone of the BNP is Anogeissus latifolia dominated forest with propensity to dry season fire. The diversity and structure of the forest is comparable to other dry forests in India. The big fire has resulted in $25 \%$ of the trees dead and $41 \%$ of the trees not affected at all. There was considerable proportion of trees survived after the fire. Anogeissus latifolia and Tectona grandis suffered maximum mortality because of fire. Each species had differential rates of survival after the fire.

\section{Acknowledgements}

We thank the Ministry of Environment and Forests, Government of India for financial support to our center. We thank the Karnataka Forest Department specially Shri. B. K. Singh IFS, PCCF (wildlife), Dr.
Swaminath IFS Additional PCCF (wildlife) and Shri. Hanumanthappa, IFS DCF, Bandipur National Park for permission and encouragement. We thank Mr. Bharanaiah, Mr. Mani and several field assistants who helped during the enumeration. We also thank forest officials from Bandipur who helped us during the enumeration. We also acknowledge the hospitality of the Bandipur forest staff during the enumeration.

\section{References}

Gadgil M., Meher-Homji V.M., 1985. Land Use and Productive Potential of Indian Savannas. In: Ecology and Management of World's Savannas (eds. J.C. Tothill and J.C. Mott), Australian Academy of Science, Canberra,

pp. 107-113.

Gadgil M., Chandran M.D.S., 1988. On the history of Uttara Kannada forest.In: Dargavel, J. Dixon, K. Semple, N (Eds). Changing Tropical Forests. Center for Resource and Environmental Studies, Canberra. pp 47-58.

Gadgil M., Guha R., 1993. This fissured land. Oxford University Press. New Delhi.

IMD. 1984. Climate of Karnataka State. India. Meteorological Department, Government of India.

Kodandapani N., Cochrane M.A., Sukumar R., 2004. Conservation threat of increasing fire frequencies in the Western Ghats, India. Conservation Biology. 1553-1561.

Kodandapani, N.. Cochrane M.A., Sukumar R., 2008. A comparative analysis of spatial, temporal and ecological characteristics of forest fires in seasonally dry tropical ecosystems in the Western Ghats, India. Forest Ecology and Management. 256: 607-617.

Mehta V.K., Sullivan P.J., Walter M.T., Krishnaswamy J., De Gloria S.D., 2008a. Ecosystem impacts of disturbance in a dry tropical forest in southern India. Ecohydrology. 1: 149-160. 
Mehta V.K., Sullivan P.J., Walter M.T., Krishnaswamy J., De Gloria S.D., 2008b. Impacts of disturbance on soil properties in a dry tropical forest in southern India. Ecohydrology 1: 161-175.

Prasad S.N., Sharatchandra H.C., 1984. Primary production and consumption in the deciduous forest ecosystem of Bandipur in south India. Proceedings of Indian Academy of Sciences (Plant Science) 93: 83-97.

Pascal J.P., 1982. Bioclimates of the Western Ghats. Institut Francais de Pondicherry: Pondicherry, 1:500000.

Prasad S. N., Hegde M., 1986. Phenology and seasonality in the tropical deciduous forest of Bandipur, south India. Proceedings of the Indian Academy of Sciences (plant Sciences) 96: 121-133.

Prasad A.E., 2009. Tree community change in a tropical dry forest: the role of roads and exotic plant invasion. Environmental Conservation.36:201-207.

Puyravaud J.P., Sridhar D., Gaulier A., Aravajy S., Ramalingam S., 1995. Impact of fire on a dry deciduous forest ion the Bandipur National Park, southern India: Preliminary assessment and implications for management. .Current Science. 68:745-751.

Saha S., 2001. Vegetation composition and structure of Tectona grandis (teak, Family Verbanaceae) plantations and dry deciduous forests of central India. Forest Ecology and Management. 148: 159-167.

Saha S., 2002. Anthropogenic fire regime in a tropical deciduous forest of central India. Current Science. 82: 101-104.

Saha S., Howe H.F., 2003. Species composition and fire in a dry deciduous forest. Ecology. 84: 3118-3123.

Saha S., Howe H.F., 2001. The Bamboo Fire Cycle Hypothesis: A Comment. The American Naturalist. 158:659-663.
Saha S., Howe H.F., 2006. Stature of Juvenile Trees in Response to Anthropogenic Fires in a Tropical Deciduous Forest of Central India. Conservation and Society. 4: 619-627.

Sharatchandra H.C., Gadgil M., 1975. A year of Bandipur. Journal of Bombay Natural History Society. 72: 623-647.

Somashekar R. K., Ravikumar P., Mohan Kumar C.N., Prakash K.L., Nagaraja B.C., 2009. Burnt area mapping of Bandipur National Park, India using IRS 1C/1D LISS III data. J. Indian Soc. Remote Sens. 37:37-50.

Sukumar R., Suresh H.S., Dattaraja H.S., Joshi N.V., 1998. Dynamics of a Tropical Deciduous Forest: Population Changes (1988 through 1993) in a 50-ha Plot at Mudumalai, Southern India. In: Forest Biodiversity, Research and Modeling: Conceptual Background and Old World Case Studies (eds. S. Dallamier and J.A. Comiskey), Smithsonian Research Institution, USA.

pp. 495-506.

Sukumar R., Suresh H.S., Dattaraja H.S., Srinidhi S., Nath C., 2005. The dynamics of a tropical dry forest in India: climate, fire, elephants and the evolution of life-history strategies. In: Burslem, DFRP, MA Pinnard Hartley, SE (Eds.) Biotic interactions in the tropics: Their role in the maintenance of species diversity. Cambridge University press. Cambridge.

Submitted: 29.07.2013

Accepted: 15.11.2016 